\title{
OPEN ACCESS IN THE DISSEMINATION OF SCIENTIFIC KNOWLEDGE IN PSYCHOLOGY
}

\author{
Mario Ulises Martínez-Quintana, Julio C. Penagos-Corzo \\ University of the Americas, San Pedro Cholula, México \\ E-mail: mario.martinezqa@udlap.mx, julioc.penagos@udlap.mx
}

\begin{abstract}
The purpose of this study is to compare the features of Open Source and Open Access movements against those of the classic publishing model. It is argued that scientific dissemination is hindered by the continuous rise of academic journals prices, while the quality of research may be impaired by conflicts of interest arising from the commercialization of scientific knowledge. This study also shows some dissemination tendencies in English and Spanish Psychology journals. It is hinted that standard publication and editorial dissemination processes do not appear to be adjusting quick enough, to follow the technological and social changes required by the current scientific production. The authors of the present study conclude that Open Access scientific publishing could ensure a higher efficiency in the distribution of scientific knowledge in comparison to the standard publishing model. In addition it is conjectured that Open Access publishing might also reduce the incidence of conflicts of interests.
\end{abstract}

Key words: copyright, intellectual property, open access, open source, scientific publishing.

\section{Introduction}

The principal instrument in the process of disseminating scientific knowledge is publishing in academic journals. This process generally follows a system where the editor may have the final word on what should be published (Dye, 2007; Lindsey, 1979). A fundamental part of the system is based on conceding legal rights to publishing houses with the aim of assisting them in their distribution operations (American Psychological Association, 2010). This marketing system has a considerable number of problems, which are outlined later on.

Generally, authors are legally impeded from distributing their published work and making it freely available. The peer reviewed academic journals of the American Psychological Association (APA), for example, only allows authors to publish a copy of a paper, whether on their personal website or on the site of the institution which they belong to. In addition, the manuscript copy should met these requirements: The paper has been accepted, its specified that the material is under APA copyright, a link to the APA website is included and its specified that it is not the published version (American Psychological Association, 2010, p. 239). The APA does not allow the published article to appear in any repository that not belong to the APA nor does provide digital copies of the published version for this purpose. Furthermore, authors are forbidden from digitally scanning the version published by the APA. 
Another of the most notable problems is the continuous increase in price of academic journals (McGuigan, 2004; Pascarelli, 1990). Pascarelli (1990) notes that the prices of academic journals Volume 1, 2012 have been continually increasing over years. Medical journals have quadrupled in price between 1977 , when their average cost was $\$ 51$ dollars, and 1989, when their prices had risen to \$199 dollars. Some believe that, given the continual increase in the prices of articles, many workers in the clinical sector will have limited access to evidence which could be used as a manual in practice and that, moreover, some researchers will be unable to view the full range of examinations previously carried out in their field, which could in turn increase redundancy in research and lead to biased results (Brown S. , 2004). Access to high-impact articles; normally require a paid subscription or the purchase of the article, usually at a price of around 30 dollars. In this work, 15 high-impact journals in Psychology where identified; of these, only one (Psychological Science) offers ways to freely access complete papers.

Table 1. Periodical Publications that stand out by their impact favor.

\begin{tabular}{lll}
\hline $\begin{array}{l}\text { Annual Reviews (Psychology) } \\
(22.750)^{*}\end{array}$ & $\begin{array}{l}\text { Personality and Social Psychology } \\
\text { Review }(6.594)^{*}\end{array}$ & $\begin{array}{l}\text { Journal of Personality and Social } \\
\text { Psychology }(4.732)^{*}\end{array}$ \\
\hline $\begin{array}{l}\text { Behavioral and Brain Sciences } \\
(19.04)^{*}\end{array}$ & American Psychologist $(6.537)^{*}$ & $\begin{array}{l}\text { Journal of Abnormal Psychology } \\
(4.515)^{*}\end{array}$ \\
\hline Psychological Bulletin (12.854)* & $\begin{array}{l}\text { Advances in Experimental Social } \\
\text { Psychology }(6.083)^{*}\end{array}$ & $\begin{array}{l}\text { Journal of Experimental Psychology: } \\
\text { General }(4.701)^{*}\end{array}$ \\
\hline $\begin{array}{l}\text { Trends in Cognitive Science } \\
(11.664)^{*}\end{array}$ & $\begin{array}{l}\text { Journal of Cognitive Neuroscience } \\
(5.382)^{*}\end{array}$ & Psychological Methods $(4.364)^{*}$ \\
\hline $\begin{array}{l}\text { Psychological Review }(9.082)^{*} \\
\text { Impact factor is shown in parenthesis. } \\
* \text { Restricted Access. } \\
\text { ** Some free Access to full papers. }\end{array}$ & Psychological Science $(5.090)^{* *}$ & $\begin{array}{l}\text { Journal of Applied Psychology } \\
(3.840)^{*}\end{array}$ \\
\hline
\end{tabular}

Other studies have highlighted the fact that rendering a scientific product into a commercial good may lead to conflicts of interests in research (Friedman \& Richter, 2004; Pachter, Fox, Zimbardo, \& Antonuccio, 2007; Truscott, Baumgart, \& Rogers, 2004), for example, when scientific research is financed by a body that in turn would benefit from certain results in such investigation (Friedman \& Richter, 2004). In relation to this, some researchers point out that, even though these conflicts of interests are particularly evident in the pharmaceutical and biotechnological sectors, Psychology is not exempt from bias caused by these conflicts (Pachter, Fox, Zimbardo, \& Antonuccio, 2007; Truscott, Baumgart, \& Rogers, 2004).

There is also the possibility that the interests of the reviewers affect the results of their work. For example, if the results of the study they are examining are contrary to those reported in their own study, or if they are conducting a similar work and decide to make unethical use of the information they have been entrusted with. If the reviewer believes the publication of the paper under evaluation could affect how his own paper is received, he may impede or delay his revision.

Further bias occurs when editors choose the material to be published based on economic and positioning factors rather than on the quality of the studies submitted for review, such as by seeking to increase their impact factor (Matías-Guiu \& García-Ramos, 2008).

It is probably for these reasons that the Open Access concept, with an important influence of the Open Source movement (Willinsky, 2005), has gained popularity among a significant number of researchers, some of which have begun an open scientific publication platform (Brown, Eisen, \& Varmus, 2003). Open Source ideology proposes a viable model of distributing knowledge that could prevent some conflicts of interests at the same time it solves the problem of the continuous increase in prices known as the Serials Crisis. In the Open Access distribution model, having a higher impact does not mean an increase in earnings by the commercialization of individual articles.

The foregoing suggests that the current system of developing and distributing scientific knowledge in Psychology is detrimental to the communication and quality of knowledge. On the other 
hand, there exist other models for developing and distributing knowledge, such as Open Source, which have proved to be advantageous and which could be used to correct and/or improve publication and editorial dissemination mechanisms in Psychology. Furthermore, the collaborative and free nature of Open Source systems could facilitate the dissemination of knowledge and, therefore, the development of science.

\section{Important Definitions}

Herein below, some of the fundamental notions regarding the concept of Open Access publishing will be outlined.

\section{Open Source}

Generally, Open Source Software is defined as any program with a source code that has been released for its use and modification; as far as users and developers deem necessary. It is normally developed as a freely distributed public collaboration (Johns Hopkins Institute, 2010). One such example is the Linux operating system. The term Open Source has also been used to refer to an ideological movement that shares common features with the Open Source Software but that has already overgrown this field (Mercer, 2007; Munos, 2006).

\section{Open Access}

Open Access gained popularity in 1990, partly due to the facilities offered by modern technology in distributing scientific material, but also as a reaction to the phenomenon known as Serials Crisis (Björk, Welling, Laakso, Majlender, Hedlund, \& Guðnason, 2010). The Open Access movement signaled a paradigm shift; research results were no longer subject to exclusive and privileged access, and were now freely accessible. One of the most important reasons in the surge of this trend is to increase the access to information that in turn may increase the impact of research findings. In the case of the investigations subsidized with public funds, it is intended to avoid for the parties involved to pay again for the right to see the findings (Greyson, Morrison, \& Waller, 2010), since they have already paid for this in tax.

A publication is considered to be Open Access when the copyright holder allows free access, use and distribution of the work. In turn, the creation and distribution of works stemming from his own in any medium and for any purpose, is approved, provided that the author is properly attributed. The work must also be published in a repository supported by an established academic, government or other institution whose objectives include free distribution and long term archiving (Bethesda Meeting, 2003).

\section{Open Source and Open Access Relation}

Looking back at the beginnings of the Open Access movement yields only a bit of information regarding the intimate yet largely overlooked relation between Open Source and Open Access. Even though some events of the Open Access movement can be traced back as far as 1966 (Sauber, 2009), the modern definition of Open Access is normally attributed to the Budapest Open Access Initiative (BOAI) launched by the Open Society Foundations in 2002 (Hagemann, 2012). This initiative was closely followed later by the Bethesda Statement and the Berlin declaration in 2003 (Sauber, 20042010). A brief inspection of all three declarations (Budapest Open Access Initiative, 2002; Bethesda Meeting, 2003; Max Planck Society, 2003) provides with little evidence, if any, regarding the relation between Open Source and Open Access. As if the development of the Open Access concept was independent from Open Source.

Hence the authors of this study pose the question, would the Open Access movement be as successful as it is now, without the contributions of the Open Source movement? Willinsky (2005) notes "open access is being supported at every turn by the use of open source software that is avail- 
able for managing and indexing both institutional repositories and journals..." In this regard assistant librarian at Trinity College Dublin, Niamh Brennan adds: "The move towards open access, starting Volume 1, 2012 about 2000, has paralleled the take-off of open source software and [it's linked very, very strongly to open source] she says" (The Irish Times, 2007, para. 7). Willinsky (2005) however goes beyond this in his paper "The unacknowledged convergence of open source, open access and open science" by tracing the similitudes between the aforementioned concepts and recognizing the importance of acknowledging this convergence.

To trace a line that separates both movements its not only unnecessary but could also hinder the admission of other Open Source mechanisms and qualities to the area of scientific research. In this matter projects like Zotero and JabRef have clearly gotten the right idea regarding the importance of providing free and open source software tools, which empowers the researchers ability to better manage their references and citations; without the need of paying for expensive proprietary licenses. In addition projects like Mendeley and ResearchGate bet towards the use of social networks, in order to enhance researchers collaboration, very much like Open Source Software networks have done for a long time. Regarding the open technologies on behalf of the scientific journal publication, the Public Knowledge Project (Owen \& Stranack, 2007) is an outstanding example of the Open Source and Open Access integration.

\section{Licenses: Copyright and Copyleft}

Copyright, or intellectual property law, regulates control over the use and dissemination of ideas and information. It stipulates that an author has the exclusive rights to reproduce, distribute and conduct any literary, musical or artistic work (Encyclopaedia Britannica, 2010). Copyleft is a category of licenses that are characterized by the use of intellectual property law to guarantee the right to use and distribute copies and modified versions of the licensed product (Mederos, 2007). Licenses that could be classified as Copyleft are the licenses developed by Creative Commons (CC). $\mathrm{CC}$ is the name of a not-for-profit organization founded in the United States that aims to promote the distribution of creative material. Therefore it facilitates the use, distribution and creation of any work in any of its six main licenses (Creative Commons, $2010 \mathrm{~A}$ ). CC is also the name which the set of licenses created by the organization is commonly known by, although it is worth mentioning that the variety of legal restrictions between these is quite wide.

To achieve its objective, this organization attempts to provide its users with legally binding licenses that have a "translated" or simplified version, making it easy to comprehend for people unfamiliar with the legal jargon. The use of copyright licenses which are different from the classic "all rights reserved" is thereby facilitated for people wanting to share their work but who, for different reasons, do not have the interests or knowledge necessary for using a classic, or seemingly more complex, license than CC (Creative Commons, 2010 B).

The most widespread Copyleft license is currently that published by the Free Software Foundation (FSF), the GNU General Public License or GNU GPL, used by most Open Source Software (Free Software Foundation, 1996 - 2008). The legal version of this license which is applicable for documents is named; GNU Free Document License (GFDL) and, until June 2009, was the main license used by Wikipedia to distribute its content.

As of June 2009, due to compatibility problems with the GFDL license and with the help of both the FSF and the organization known as CC, Wikipedia has changed its license to: Creative Commons Attribution - Licensing (CC-BY-SA; Wikimedia Foundation, Inc., 2009).

\section{Case Description}

The systems described below are examples that, due to their very features, stand out as models of openness. At the same time, they demonstrate sustainability, facilitate collaborative development models and can be used efficiently in the dissemination of knowledge. 
OF PSYCHOLOGY

IN THE $21^{\text {st }}$ CENTURY Volume 1, 2012

40

\section{Wikipedia}

Wikipedia is an online encyclopedia of voluntary contribution with open content in several languages. Founded by Jimmy Wales and Larry Sanger, the English language version was launched on January 15,2001 as a side-project with the main objective of speeding up the creation of content for the now extinct encyclopedia Nupedia. The latter project was aimed at creating a peer-review encyclopedia written by highly qualified authors (Ortega, 2009). However given the success of Wikipedia over Nupedia, the later was cancelled.

Wikipedia quickly flourished after receiving considerable media attention and soon afterwards, on March 15, the German version of the site was created, the first in a language other than English. In May of that year the encyclopedia was started in several languages, among which featured a Spanish version (Ortega, 2009).

For the most part, the encyclopedia content is available to be reused under the terms of the CCBY-SA license (Wikimedia Foundation, Inc., 2009), which means that content may be copied and distributed under similar licenses provided that the original author is properly referenced. Licenses for other materials may be even less restrictive, such as a work being granted as public domain.

Even though Wikipedia has no formal review process, some studies suggest that the quality of its articles can be reasonably high. In a study published by Nature, carried out by Giles in 2005 (cited in Baytiyeh \& Pfaffman, 2010), 42 article pairs were chosen from Wikipedia and the Encyclopaedia Britannica. On average, three errors were found per article in the Encyclopaedia Britannica and around four on Wikipedia.

Organization. Wikipedia's content is created, edited and maintained by volunteers around the world. Just about anyone can use and change the content of the encyclopedia. Regular collaborators form a collective that gets together on Talk Pages to discuss articles modifications and the management of the encyclopedia (Baytiyeh \& Pfaffman, 2010).

The fact that Wikipedia allows free editing can lead to a significant number of erroneous or unsubstantiated modifications and site vandalism. One of the systems used by collaborators to maintain the integrity of articles has been added to the software engine. The Watch function sends interested editors a notification when a change is made to the article being watched, making it easier to review recent edits. On the other hand new self-correction and moderation methods have also been implemented. In October 2001, Jimmy Wales selected a small group of administrators whose objective was to correct abuses of the encyclopedia. These users have access to special functions of the software engine and are able to completely delete and block articles or users so as to prevent more changes, among other functions. These administrators are currently selected by the Wikipedia user community (Baytiyeh \& Pfaffman, 2010).

One of the most important and complex systems for the progress of articles is the process by which some articles receive the "Featured Article" status. For an article to be given this status, editors must agree that it meets all of the requisites described in the requirements set out by Wikipedia for featured articles. Likewise, an article can lose its "featured" status if it no longer satisfies the requirements set out in the Wikipedia guidelines. This normally occurs when the requirements become stricter (Viegas, Wattenberg, \& McKeon, 2007).

\section{Public Library of Science}

Public Library of Science, often known by its initials "PLoS", is a non-profit academic Open Access journal that states its aim as making scientific and medical knowledge a public resource (Public Library of Science, 2010). As a non-profit organization, PLoS is exempt from tax and some financial information is made public through the United States Inland Revenue Service (IRS) 990 form, as stated by the manager of community relations and marketing (Okubo, D. personal communication, April 5, 2011).

PLoS is based in San Francisco, California, and distributes, among other peer-reviewed journals, PLoS Biology, PLoS Medicine and PLoS ONE (Public Library of Science, 2009). Its official website states that the organization is governed by a board of directors and that each journal has an independent editorial board (Public Library of Science, s.f. B). The publishing house claims to 
support and use the definition of the Bethesda Meeting (Bethesda Meeting, 2003) in defining Open Access publications, with the reservation that the license which they publish under, the Creative Volume 1, 2012 Commons Attribution license (CC-BY), allows material stemming from articles to be used commercially (Public Library of Science, s.f. A).

In a statement published by its founders, some of the reasons by which they decided to start publishing are discussed. One of its aims is to facilitate scientific research for those who cannot afford pay subscriptions for academic journals. Another reason for the creation of PLoS is the assumption that by freeing scientific information from barriers created by the classic publishing model, new tools of integration and navigation will enable large amounts of information to be organized and analyzed. The founders point out their desire to start a revolution in how science is distributed and to provide a valuable and feasible example of Open Access publishing (Brown, Eisen, \& Varmus, 2003). Brown et al. theorize that an alternative to the current scientific publishing model is to include the publication costs within the essential investigation expenses (2003).

PLoS has developed (and continues to develop) an Open Source publication platform called TOPAZ, which in theory should be capable of enabling semantic networks and computer literature analysis. PLoS ONE was the first journal to employ this software. However since May 2009, all other PLoS journals have also been using this publication platform (Public Library of Science, 2009).

Organization. This publishing house covers part of its production costs through publication fees which may be paid by the research authors or their sponsors (e.g. Universities). PLoS offer total or partial exemption from the publication fee for authors who do not have the financial means to pay it. Whatever the case, the author's ability to pay the publication fee is concealed from the editor or reviewer to prevent this from influencing their decisions on publication (Public Library of Science, s.f. C). All other publication costs are financed by donations from philanthropic foundations. However, on its official website its stated that the company is committed to achieving financial independence so that, as the journal grows, it becomes less reliant on charity donations (Public Library of Science, s.f. B). One of the most important differences between PLoS and traditional academic journals is that the authors publishing in PLoS maintain the legal right to use published articles. Authors are only required to license the manuscript as CC General Attribution (Public Library of Science, s.f. D).

PLOS ONE review process. As well as following the regular guidelines for most peer-review publications, PLoS ONE accepts all articles that demonstrate high academic quality and do not refuse articles based on subjective relevance as perceived by the editors. Accordingly, PLoS would not refuse manuscripts for any of the following reasons: The article 1) is outside the journal's sphere, 2) is too specialized, 3) is of little public interest, 4) is not original enough, or 5) is too complicated (MacCallum, 2006).

For its size, PLoS ONE has a large number of academic editors (around 1300) whose main role is to organize the peer-review process until a decision is taken over the publication of the manuscript (PLoS ONE, s.f. A). When submitting a manuscript, authors have the possibility to exclude an academic editor or reviewer. The editorial team will respect this decision as long as it does not interfere with the article being reviewed objectively (PLoS ONE, s.f. B). Once the manuscript is passed to the Academic Editors, they are responsible for leading the review process, whether they themselves act as reviewers or they select external reviewers to look at the manuscript (PLoS ONE, s.f. A). PLoS ONE mainly publishes online and its contents can be assessed by the community with comments and public evaluations (MacCallum, 2006).

Another PLoS policies, which were implemented with the objective of preventing conflicts of interest and academic misconduct, include detailed regulations over the declaration of interests that may hinder the authors and editors objectivity (PLoS ONE, s.f. C).

\section{Final Remarks}

\section{Considerations Over the Use of Open Access Type Licenses}

The global impact that the Internet has had on popular culture, the economy and within the scientific development in general must not be ignored. This is perhaps the reason that the Open 
Source movement continues to gain popularity in a number of spheres outside of software creation (Mercer, 2007; Munos, 2006). Practices which were previously exclusive to specialist groups, for example the use of wikis, have proved to be useful in many other areas and their influence has gained ground in public use. It is with this proficient approach in the use of technology that the criticism of inappropriate use of copyright laws is based on. Laws, which initial aim, were to give authors the legal power over their own works so that they could profit as they saw fit. However, it is now a common practice to strip authors of the legal rights over their work in order to facilitate the work of publicists. In academia, this practice proved useful for many years, when it was impossible for an individual to publish the fruits of their work due to correction, printing and transport costs. Unfortunately, it would seem that, in recent years, intellectual property laws have been exploited by some companies which, far from seeking efficient selection and distribution of intellectual material, may look for financial benefits over scientific progress (Brown S. , 2004; Miller, 2009; Willinsky, 2005).

The use of Open Access licenses has increased recently in the publication of academic articles. In Ibero-America, this has given the ground for projects indexing open articles and journals. The Network of Scientific Journals of Latin America and the Caribbean, Spain and Portugal (Red de Revistas Científicas de América Latina y El Caribe, España y Portugal; Redalyc) is a clear example of the benefits of Open Access in the Ibero-American science scene. The Redalyc website is an academic repository which was opened to the public in 2002 and whose objective is "to contribute to the dissemination of scientific activity", under the motto "la ciencia que no se ve no existe" (science you don't see doesn't exist; Redalyc, s.f. A).

On the website of this repository, editors point out that “...unrestricted scientific communication improves scientific development, the economy and the quality of life for the inhabitants of Ibero-American countries and the world" (emphasis added). Redalyc currently indexes a total of 758 scientific journals (Redalyc, s.f. C). In the official website of Redalyc the definition of Open Access given by the Bethesda Meeting is acknowledged (2003; Redalyc, s.f. B). It can therefore no longer be said that the practice of Open Access publishing is not conventional or is limited to specific fields.

\section{Considerations Over the Future of Scientific Publications}

One of the aims of this text has been to show that the dominant system in academic dissemination is no longer ideal given current technological developments, partly due to the difficulty in accessing traditional academic repositories, which constitutes a financial cost to the user.

Open Access publishing reduces the barriers encountered by researchers who cannot pay the fees set by publishers (Björk, Welling, Laakso, Majlender, Hedlund, \& Guðnason, 2010; Lor, 2007; Willinsky, 2005). Any person interested, be it a practitioner, researcher or educator, is able to study the entire range of current research. Open Access also ensures that the people interested in doing research can take part in studies without economic resources being central, with greater freedom and less bias. Allied to this, it facilitates the set-up of free, universal databases that in turn can be used as bibliometric indicators (e.g. Redalyc).

Perhaps the most important aspect is the empowerment of collaborative research. When bibliographic materials are freely organized, reproduced and distributed, it provides researchers with the tools that in turn facilitate the work of international teams. A good example of this is the project entitled OpenWetWare developed by the Massachusetts Institute of Technology (Waldrop, 2008). OpenWetWare was initially conceived as a medium for sharing information between two laboratories. However, its usefulness as a forum for developing and exchanging ideas has made the site a hub of international activity, taking in 15 laboratories around the world. OpenWetWare uses MediaWiki, the same web engine developed for Wikipedia, and its content is published under open licenses (OpenWetWare, 2006). Other examples where it can be clearly appreciated how open standards promote collaborative practice are PLoS Currents (PLoS Currents, 2010) and the Open Source Drug Discovery Initiative (Munos, 2006) just to name a couple.

The success of the projects, which have been outlined in this text, would not have been possible under the classic copyright model, all rights reserved. It can therefore be asserted that Open Access comes a step closer to what some authors call Science 2.0 (Waldrop, 2008). However, 
Open Access should not be the only attribute that can be recovered from the Open Source ideology. Other strategies include the formulation of transparent, open policies that facilitate collaboration Volume 1, 2012 while limiting conflicts of interests. To that effect, it is crucial to take advantage of the valuable examples set by Wikipedia and PLoS in supporting the distribution and openness of knowledge.

\section{To Conclude}

The authors of this text believe that adopting the most advanced technological instruments, which have the aforementioned features of openness, is not only ideal, but also necessary for preventing the delay of scientific knowledge creation. The likely domination of Open Access licenses in future scientific publications will present new challenges which call for creative solutions which are capable to support scientific knowledge production of never before seen magnitudes.

One of the most significant challenges that will have to be solved in the near future is the classification and organization of information. It will no longer be as easy to define where one discipline ends and another begins, or which research is relevant and which is not. With a little luck, editors can be freed from this task and it will be the academic public who decides.

On the other hand, the challenge arises of whether peer-review, a method that has proved highly useful in inspecting whether the scientific method is used appropriately, will continue to operate just as it does now. When done ethically and properly, peer-review is priceless. Unfortunately, current regulation are set up in such a way that some editors could be tempted to select articles not only on the recommendation of reviewers, but also because of the benefit that this article could bring to the journal. For example, to increase their impact factor (Matías-Guiu \& García-Ramos, 2008; Punjabi, 2010) or for financial the gain that article resale may bring to the publishing house (The PLoS Medicine Editors, 2009). Perhaps in the future, new review methods will materialize which ensures the same scientific quality as provided by classic peer-review without the aforementioned conflicts of interests. Post-publication review and open review (van Rooyen, Godlee, Evans, Black, \& Smith, 1999) are just some of the possible alternatives.

What is beyond doubt is that we are in a historic moment where a change of direction towards openness is inevitable; it is the responsibility of everyone in academia to facilitate (or impede) the transition towards a new kind of research.

\section{Note}

While finishing this manuscript, an initiative in which three highly recognized scientific institutions were to inaugurate a "top-tier" Open Access journal was announced. Without a doubt an example that the Open Access tendency addressed in this text is a desirable course to follow (Howard Hughes Medical Institute, 2011).

\section{References}

American Psychological Association. (2010). Publication Manual of the American Psychological Association (6th ed.). Washington: American Psychological Association.

Baytiyeh, H., \& Pfaffman, J. (2010). Volunteers in Wikipedia: Why the Community Matters. Journal of Educational Technology \& Society, 13 (2), 128-140.

Bethesda Meeting. (2003, July 20). Bethesda Statement on Open Access Publishing. Retrieved March 17, 2010, from Earlham College: http://www.earlham.edu/ peters/fos/bethesda.htm

Björk, B. C., Welling, P., Laakso, M., Majlender, P., Hedlund, T., \& Guðnason, G. (2010). Open Access to the Scientific Journal Literature: Situation 2009. PLoS ONE , 5 (6), 1-9.

Brown, P., Eisen, M., \& Varmus, H. (2003). Why PLoS Became a Publisher. PLoS Biology, 1 (1), e36.

Brown, S. (2004). Is Your Intellectual Property Being Pirated? Journal of Nursing Scholarship, 36 (4), 290-291. 
OF PSYCHOLOGY

IN THE $21^{\text {st }}$ CENTURY Volume 1, 2012

44

Budapest Open Access Initiative. (2002, February 14). Read the Budapest Open Access Initiative. Retrieved February 22, 2012, from Budapest Open Access Initiative: http://www.soros.org/openaccess/read

Creative Commons. (2010 B, August 4). Creative Commons. Retrieved August 26, 2010, from About Licenses: http://creativecommons.org/about/licenses/

Creative Commons. (2010 A, August 16). Frequently Asked Questions. (This page was last modified on 20 August 2010, at 22:06.) Retrieved August 26, 2010, from Creative Commons: http://wiki. creativecommons.org/Frequently_Asked_Questions\#What_problem_does_Creative_Commons_intend to_solve. $3 \mathrm{~F}$

Dye, L. R. (2007). A Review of the Review Process. Journal of Medical Toxicology , 3 (4), 143-145.

Encyclopaedia Britannica. (2010). intellectual-property law. Retrieved March 12, 2010, from Encyclopaedia Britannica: http://www.britannica.com/EBchecked/topic/911774/intellectual-property-law

Free Software Foundation. (1996 - 2008). Licenses. Retrieved March 12, 2010, from GNU Operating System: http://www.gnu.org/licenses/licenses.html

Friedman, L. S., \& Richter, E. D. (2004). Relationship Between Conflicts of Interest and Research Results. Journal of General Internal Medicine , 19 (1), 51-56.

Greyson, D., Morrison, H., \& Waller, A. (2010). Open Access in Canada: A Strong Beginning. Feliciter , $56(2), 60-63$.

Hagemann, M. (2012, February 14). Ten Years On, Researchers Embrace Open Access. Retrieved February 24, 2012, from Open Society Foundations: http://blog.soros.org/2012/02/ten-years-on-researchersembrace-open-access/

Howard Hughes Medical Institute. (2011, June 27). Leading Research Organizations Announce Top-Tier, Open Access Journal for Biomedical and Life Sciences. Retrieved Jul7 13, 2011, from Howard Hughes Medical Institute: http:/www.hhmi.org/news/20110627.html

Johns Hopkins Institute. (2010). Glossary. Retrieved March 7, 2010, from Information Technology @, Johns Hopkins Institute: http://it.jhu.edu/glossary/mno.html\#O

Lindsey, D. (1979). The Editorial Review Process: Is It a Sacred Cow? Contemporary Sociology, 8 (6), 819-824.

Lor, P. J. (2007). Libraries in times of open access: Paper presented at the APE 2007: Academic Publishing in Europe Conference "Innovation \& Publishing”, Berlin, 23-24 January 2007. Information Services \& Use, 27 (4), 193-205.

MacCallum, C. J. (2006). ONE for all: the next step for PLoS. PLoS Biol , 4 (11), e401--e401.

Matías-Guiu, J., \& García-Ramos, R. (2008). El factor de impacto y las decisiones editoriales. (Spanish). Neurología , 23 (6), 342-348.

Max Planck Society. (2003, October 22). Berlin Declaration. Retrieved February 22, 2012, from Open Access at the Max Planck Society: http:/oa.mpg.de/lang/en-uk/berlin-prozess/berliner-erklarung/

McGuigan, G. S. (2004). Publishing Perils in Academe: The Serials Crisis and the Economics of the Academic Journal Publishing Industry. Journal of Business $\mid \&$ Finance Librarianship, 10 (1), 13-26.

Mederos, M. R. (2007). La difusión de las creaciones en la era digital: El Copyleft para distribuir creaciones en la era digital. (Spanish). ACIMED, 15 (1), 1.

Mercer, J. (2007). Wikipedia and 'open source' mental health information. The Scientific Review of Mental Health Practice , 5 (1), 88-92.

Miller, R. (2009). Open Access Battles to Democratize Academic Publishing. EContent, 32 (3), 32-36.

Munos, B. (2006). Can open-source R\&D reinvigorate drug research? Nature Reviews Drug Discovery , 5 (9), 723-729.

Okubo, D. (2011, April 5). Institutional Relations Manager. (U. Martinez-Quintana, Interviewer)

OpenWetWare. (2006, January 24). Science 2.0. Retrieved June 05, 2010, from OpenWetWare: http://www. openwetware.org/wiki/Science_2.0

Ortega, J. F. (2009). Wikipedia: A quantitative analysis. Universidad Rey Juan Carlos, Ingenieria de Telecomunicacion, Madrid.

Owen, G., \& Stranack, K. (2007). The Public Knowledge Project and the Simon Fraser University Library: A partnership in open source and open access. Serials Librarian , 55 (1/2), 140-167. 
Pachter, W. S., Fox, R. E., Zimbardo, P., \& Antonuccio, D. O. (2007). Corporate funding and conflicts of interest: A primer for psychologists. American Psychologist , 62 (9), 1005-1015.

Pascarelli, A. M. (1990). Coping strategies for libraries facing the serials crisis. Serials Review , 16 (1), 75.

PLoS Currents. (2010, November 16). PLoS Currents FAQs:Rapid and open sharing of new research data, analyses, and ideas, 5. Retrieved June 09, 2011, from PLoS Currents: Tree of Life: http://knol.google. com/k/plos/plos-currents-faqs/28qm4w0q65e4w/75\#

PLoS ONE. (s.f. A). PLoS ONE Editorial and Peer-Review Process. Retrieved May 22, 2011, from PLoS ONE: http://www.plosone.org/static/review.action

PLoS ONE. (s.f. B). PLoS ONE. Retrieved May 22, 2011, from PLoS ONE Editorial and Publishing Policies: http://www.plosone.org/static/policies.action

PLoS ONE. (s.f. C). PLoS ONE. Retrieved May 22, 2011, from PLoS Policy on Declaration and Evaluation of Competing Interests: http://www.plosone.org/static/competing.action

Public Library of Science. (2009, June 8). Announcing the first PLoS Progress Report. Retrieved September 21, 2010, from The official PLoS BLogs: http://blogs.plos.org/plos/2009/06/announcing-the-firstplos-progress-report/

Public Library of Science. (s.f. A). Definition of Open Access. Retrieved March 12, 2010, from Public Library of Science: http://www.plos.org/oa/definition.php

Public Library of Science. (s.f. B). Frequently Asked Questions. Retrieved October 19, 2010, from Public Library of Science: http://www.plos.org/about/faq.php

Public Library of Science. (s.f. D). Open Access License. Retrieved November 04, 2010, from Public Library of Science: http://www.plos.org/journals/license.php

Public Library of Science. (s.f. C). Publication Fees for PLoS Journals. Retrieved November 7, 2010, from Public Library of Science: http://www.plos.org/journals/pubfees.php

Public Library of Science. (2010, July 20). The Official PLoS Blog. Retrieved September 21, 2010, from Announcing the PLoS Progress Update: http://blogs.plos.org/plos/2010/07/announcing-the-plosprogress-update/

Punjabi, P. P. (2010). The Impact of the Impact Factor. Perfusion , 25 (1), 3-4.

Redalyc. (s.f. B). Declaración sobre Acceso Abierto. Retrieved June 05, 2010, from Redalyc: http://redalyc. uaemex.mx/redalyc/media/principal/servicios/open_access.html

Redalyc. (s.f. C). Homepage. Retrieved June 05, 2010, from SISTEMA DE INFORMACIÓN CIENTÍFICA REDALYC: http://redalyc.uaemex.mx/

Redalyc. (s.f. A). Presentacion. Retrieved June 08, 2010, from Redalyc: http://redalyc.uaemex.mx/redalyc/ media/principal/auxHemeroteca/presentacion.html

Sauber, P. (2004-2010). Open Access Overview. Retrieved February 23, 2012, from Earlham College: http:// www.earlham.edu/ peters/fos/overview.htm

Sauber, P. (2009). Timeline of the Open Access Movement. Retrieved February 23, 2012, from Earlham College: http://www.earlham.edu/ peters/fos/timeline.htm

The Irish Times. (2007, December 14). Free to Learn.

The PLoS Medicine Editors. (2009). An Unbiased Scientific Record Should Be Everyone's Agenda. PLoS Med, 6 (2).

Truscott, S. D., Baumgart, M. B., \& Rogers, K. M. (2004). Financial conflicts of interest in the school psychology assessment literature. School Psychology Quarterly, 19 (2), 166-178.

van Rooyen, S., Godlee, F., Evans, S., Black, N., \& Smith, R. (1999). Effect of open peer review on quality of reviews and on reviewers' recommendations: A randomised trial. BMJ: British Medical Journal (International Edition), 318 (7175), 23.

Viegas, F. B., Wattenberg, M., \& McKeon, M. M. (2007). The Hidden Order of Wikipedia. (pp. 445-454). Berlin, Springer.

Waldrop, M. (2008). SCIENCE 2.0. Scientific American, 298 (5), 68-73.

Wikimedia Foundation, Inc. (2009, May 21). Wikimedia community approves license migration. Retrieved 
ISSN 2029-8587

PROBLEMS

OF PSYCHOLOGY

IN THE $21^{\text {st }}$ CENTURY

Volume 1, 2012

46

Mario Ulises MARTÍNEZ-QUINTANA, Julio C. PENAGOS-CORZO. Open Access in the Dissemination of Scientific Knowledge in Psychology

June 13, 2011, from Wikimedia Foundation: http://blog.wikimedia.org/2009/05/21/wikimediacommunity-approves-license-migration/

Willinsky, J. (2005). The unacknowledged convergence of open source, open access, and open science. First Monday, 10 (8).

Advised by Maria Ledzińska, Warsaw University, Poland

Received: February 12, 2012

Accepted: March 09, 2012

Mario Ulises Martínez- $\quad$ Psychologist, Assistant, University of the Americas (UDLAP), Psychology Department, Ex

Quintana Hacienda Sta. Catarina Martir. Cholula, 72810, Puebla, México.

E-mail:mario.martinezqa@udlap.mx

Julio C. Penagos-Corzo MC, Professor (Chief of Psychology Laboratories), University of the Americas (UDLAP),

Psychology Department. Ex Hacienda Sta. Catarina Martir, Cholula, 72810, Puebla, México.

E-mail: ulioc.penagos@udlap.mx

Website: http://penagos.net 